\title{
Two Films about Becoming Plant
}

Laura U. Marks

Simon Fraser University

Little Forest

Film by: Yim Soon-Rye

A Shape of Things to Come

Film by: Lisa Marie Malloy and JP Sniadecki

Becoming like a plant involves spending time with plants, studying them, mindfully ingesting them, and changing one's scale-both shrinking and diffusing-to occupy the scale of a plant. A fiction film from Korea, Yim Soon-Rye's Little Forest (20I8), and a documentary from the United States, Lisa Marie Malloy and JP Sniadecki's A Shape of Things to Come (2020), present creative vocabularies for stories of characters who become-plant. In both movies, the protagonists develop self-sufficient, earth-friendly ways of living and, more or less emphatically, reject the capitalist social order. Each film is supported by beautiful cinematography, arising from the elegant watchfulness of Lee Seung-hoon, and the extraordinary intimacy and trust Malloy and Sniadecki gained with their outlaw character.

Little Forest (based on Daisuke Igarashi's 2004 manga) begins with Hye Won (Kim Tae-Ri of The Handmaiden) working in a convenience store in Seoul, having flunked her exams and now too old (at 27) to marry. Her boyfriend puts her down because she's no longer in university, but the last straw in Hye Won's meager urban life is when a mouthful of takeout rice proves so disgusting that she has to spit it out. She returns to her abandoned family home in her father's rural village. As she re-creates the recipes she learned from her mother (Moon Soo-Ri, in flashbacks), Hye Won develops an intimacy with the seasonal rhythms. A Shape of Things to Come follows a bearded, leathery loner (named Sundog, apparently, but I didn't catch it on first viewing) who ingeniously lives off the land in the Sonoran Desert while preparing an act of radical environmentalism. In contrast to the coming-to-wisdom narrative of Little Forest, Malloy and Sniadecki reveal little of this man's back story. 
One of the first recipes Hye Won makes is makgeolli, a milky fermented drink of rice and barley. After she layers the ingredients into a big glass jar with water and a starter, the film takes its time observing the bubbling commerce of grains and microorganisms, one of its first forays into a nonhuman perspective. Makgeolli keeps you warm on a cold night and should be drunk with friends, so Hye Won invites two old high school friends to commune over it.

In an early scene of A Shape of Things to Come, the protagonist shoots an animal from a great distance. It turns out to be a wild boar, which he has wounded in the thigh. He takes a pee while he waits for the animal to bleed out, and then waits while it gasps and finally dies. Back at his handcrafted encampment, Sundog carves out the boar's glistening guts—a treat for his dogs—skins it, and later, as the sun is setting, grills, and eats the meat.

Little Forest's seasonal recipes (all meatless!) include both traditional and innovative matters of respecting and drawing close to plant life. In the spring, Hye Won makes tempura of tender bunches of tree blossoms, acacia perhaps, which shatter enticingly when she bites into them. In late fall, she threads persimmons on ingenious plastic persimmon dryers and hangs them off the verandah. Her girlfriend, angry over a breakup, cooks a dish with too many hot peppers that make both women cough and weep. Hye Won tosses spaghetti with parmesan cheese and apple blossoms! The recipes' inventiveness and instinctiveness recall in flashbacks her mother, a free spirit full of good advice who left a loving note explaining why she had "abandoned" Hye Won: she needed to pursue her dream and believed she'd given her daughter the necessary skills to survive creatively and happily.

Initially, Sundog, vocalizing in chuckles and burbles, seems to have gone completely feral. Then we are surprised to hear him speaking educated English on the phone, and film expands his portrait to include the human community he is part of (there's a friendly local librarian, a celebratory dance party), and show that he is an extremely active citizen. Still, A Shape of Things to Come suggests that he desires to be claimed back to the pre-cultural world. He is building an alliance with the plants. (In an earlier cut that the filmmakers shared with me, while harvesting with a friend Sundog says, "We think they [the plants]'re working for us, but we're working for them.") He harvests opium poppy seed pods and brews laudanum. 
In the film's most primeval throughline, Sundog harvests toad venom [Bufo alvarius]: he captures toads and carefully squeezes their glands to squirt the venom onto a sheet of glass. At the end of $A$ Shape of Things to Come, he smokes a toad-venom cigarette, and we witness his dispersal from a human embodiment. He inhales the smoke and settles down under a tree. The camera moves away and allows itself to get lost in a haptic tangle of tree limbs, plants, and vines.

The end of the film is an epic sequence by Molloy in the manner of Stan Brakhage's Mothlight. For several minutes, a colorful riot of petals, leaves, and stamens invades our pupils, as though the point of view of the plants and insects has taken over the world. Doubled in a mirror image, the stamen riot visually approximates the ecstatic state of becoming-plant.

Little Forest's rebellion is a feminist rebellion against the Korean marriagecapitalist system, deftly handled in the subtlety of the narrative. Hye Sun does have a love interest, her strong and handsome friend, Eun Sook, who returned home to work on his family's farm, and who teaches her about harvesting apples, but the movie plays down this romance. The beautiful reunion hinted at the end is not with a man, but the return of her mother. The rebellion of $A$ Shape of Things to Come is far more extreme, and I hate to spoil the movie by telling you. We see Sundog testing his rifle, checking out the security around the base of an oil pipeline tower. The movie's "climax" occurs when, from an extraordinary distance, he shoots out the pipeline tower. This sequence is carefully shot and edited to prove his success. But what I find so witty is that the resulting explosion occurs far in the background of the shot. It could be obscured by holding up one's thumb, or a small opium pod.

\author{
Laura U. Marks, \\ Simon Fraser University, \\ laura_marks@sfu.ca
}

